\title{
Prevalence of Mistletoes in Fruit and Timber Trees in the Wet and Intermediate Zone of Sri Lanka
}

\author{
S.S. Yapa, A.J. Mohotti ${ }^{1}{ }^{*}$, M.A.P.K. Seneviratne, B.L. Peiris ${ }^{1}$ and K.U. Tennakoon ${ }^{2}$
}

\author{
Postgraduate Institute of Agriculture \\ University of Peradeniya \\ Sri Lanka
}

\begin{abstract}
A survey was conducted to identify the parasitic plant species occurring in timber and fruit trees during November 2015 to April 2017, in 15 Districts of Wet and Intermediate Zones of Sri Lanka using two stage stratified random sampling scheme. The parasitic plants on fruit and timber trees were identified by comparing them with the specimen in National Herbarium, Peradeniya. Host plant species were taxonomically identified after consultation of botanical experts and using species identification keys. Correlation between parameters were made using SAS software. Mistletoes infested in varying degrees in 27 perennial fruit and 20 timber tree species in different cropping systems. Dendrophthoe falcata, $\underline{D}$. neilgherrensis, $\underline{\text { Scurrulla }}$ cordifolia, Viscum articulatum,

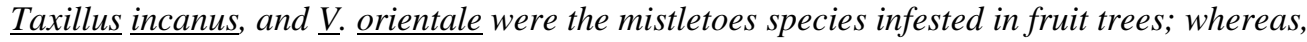
$\underline{D}$. falcata, $\underline{D} . \underline{\text { neilgherrensis, }} \underline{S} . \underline{\text { cordifolia }}, \underline{S}$. parasitica, $\underline{V}$. articulatum and $\underline{V}$. orientale were found in timber species. $\underline{D}$. falcata was the most predominent parasitic plant in both fruit and timber trees. Mangifera indica and Albizia odoratissima were the most susceptible host fruit and timber species, respectively. The study indicated that further studies are required on the increased occurrence of parasitic plants, their effects on host plants and development of control measures.
\end{abstract}

Keywords: Parasitic plants, mistletoes, host plants, timber, fruit trees

\section{INTRODUCTION}

Parasitic plants are angiosperms that meet their water and food requirements by exploiting their host plants with exquisite adaptations. There are over 4,500 species of parasitic plants occurring in a wide variety of natural plant communities from twelve orders (Press, 1989; Hibbard and Jeschke, 2001; Watson, 2009; Bell and Adams, 2011). An estimated 1\% of the flowering plants are known to be parasitic. Approximately $60 \%$ of the total parasitic flowering plants are root parasites and the others are shoot parasites. The latter, with shrubby and woody growth, is referred to as mistletoes (Watson, 2011).

Parasitic plants are known to have significant, deleterious effects on their hosts in terms of reduction of photosynthetic rate and total canopy photosynthesis (Watling and Press, 2001; Cameron et al., 2008), affecting carbohydrate nutrition (Hull and Leonard, 1964), host plant

Department of Crop Science, Faculty of Agriculture, University of Peradeniya, Sri Lanka

2 Institute of Biodiversity and Environmental Research (IBER), University of Brunei Darussalam, Gadong BE Brunei Darussalam

* Corresponding author: mohottij@yahoo.com 
mineral nutrition (Watson, 2009; Tennakoon et al., 2011), solute flux (Hibberd and Jeschke, 2001), host plant growth (Epp and Tardiff, 2004), wood quality (Agne et al., 2014), yield and quality of harvest (Muttaqin et al., 2016; Yapa et al., 2017) etc. Even they can cause mortality of the host plants (Way, 2011; Asare-Bediako et al., 2013). Parasite performance can also vary greatly depending on the type of the host (Marvier, 1998; Watson, 2009).

The occurrence of parasitic plants in Sri Lanka has been reported in many research communications (Weeraratna, 1959; Weeraratna, 1960; Tennakoon and Weerasooriya, 1998; Marambe et al., 2002; de Vlas and de Vlas-de Jong, 2014; Yapa et al., 2015; Yapa et al., 2017). Tennakoon and Weerasooriya (1998) reported 21 and 9 species each of mistletoes belong to the families Loranthaceae and Viscaceae, respectively, and 4, 4, 1 and 3 species each of root hemi-parasites belong to the families Olacaceae, Scrophulariaceae, Opiliaceae and Santalaceae, respectively. These species are spread across the montane, lowland Wet, Intermediate and Dry Zones of the country. Of these, 11 species were endemic to Sri Lanka.

The incidence of mistletoes has been noted to be high, especially in many economically important crops (Yapa et al., 2015). Yapa et al. $(2015 ; 2017)$ also reported the occurrence of parasitic plants in many Export Agriculture Crops, which includes spice and beverage crops, in Sri Lanka. However, no recent studies are available on the relative abundance of different species of mistletoes on such crops in Sri Lanka. Therefore, this study was conducted with the objective of elucidating the nature of occurrence of parasitic plants in fruit and timber species, and to identify the parasitic plant species and their host fruit and timber crops, in Wet and Intermediate Zones of Sri Lanka.

\section{MATERIALS AND METHODS}

A survey was carried out in 15 districts belonging to the Wet (WZ) and Intermediate Zones (IZ) of Sri Lanka (Table 1), during the period of November 2015 to April 2017 as a part of an ongoing, long term study. Fruit and timber tree species which were infested with mistletoes in the WZ and IZ were identified during the survey for data collection.

\section{Data collection}

Data collected during the survey were location of the sampling, province, administrative district, agro climatic zones, type of vegetation, mistletoe species and host plant species. Samples of mistletoes were collected during the survey and identified by comparing them with specimens available at the National Herbarium, Peradeniya, Sri Lanka, and were preserved using standard methods. 
Table 1. Details of the locations and percentage of lands with fruit and timber host tree species infested with mistletoes

\begin{tabular}{|c|c|c|c|}
\hline Province & District & $\begin{array}{c}\text { \% Lands with } \\
\text { infested fruit } \\
\text { species* }\end{array}$ & $\begin{array}{c}\text { \% Lands with } \\
\text { infested timber } \\
\text { species }^{\S}\end{array}$ \\
\hline Central & $\begin{array}{l}\text { Kandy (WZ), Matale (IZ), } \\
\text { Nuwara Eliya (WZ) }\end{array}$ & 46.9 & 43.11 \\
\hline Sabaragamuwa & Kegalle (WZ), Ratnapura (WZ) & 13.4 & 10.29 \\
\hline Western & $\begin{array}{l}\text { Colombo (WZ), Gampaha } \\
\text { (WZ), Ratnapura (WZ) }\end{array}$ & 8.4 & 4.41 \\
\hline Southern & $\begin{array}{l}\text { Galle (WZ), Matara (WZ), } \\
\text { Hambantota(IZ) }\end{array}$ & 6.3 & 19.11 \\
\hline Uva & Badulla (IZ), Moneragala (IZ) & 7.5 & 14.68 \\
\hline Wayamba & Kurunegala (IZ), & 16.2 & 7.35 \\
\hline Eastern & Ampara (IZ) & 1.3 & 1.05 \\
\hline \multicolumn{4}{|c|}{$W Z=$ Wet Zone $; Z=$ Intermediate Zone } \\
\hline \multicolumn{4}{|c|}{$\frac{\text { Number of lands with infested fruit species in a given province }}{\text { Total number of lands with infested fruit species in all the provinces }} * 100$} \\
\hline$\S \frac{\text { Number of lan }}{\text { Total number of }}$ & & $\frac{\text { ovince }}{\text { rovinces }} * 100$ & \\
\hline
\end{tabular}

\section{Sampling and data analysis}

A two-stage stratified random sampling scheme was used in this study. The provinces in the Wet and Intermediate Zone of Sri Lanka, the districts in each province and land extents were used as criteria for the stratification. Statistical tests of association between province, district, agro-climatic zone, and land use types with parasitic plants in infested timber and fruit tree species were also done.

\section{RESULTS AND DISCUSSION}

Infested host trees with mistletoes could be observed in all 15 districts in the Wet and Intermediate Zones. These trees were present in lands belonging to different land use types (Table 2). Most of the infested fruit and timber trees were observed in home gardens, including Kandyan forest gardens (KFG), followed by roadsides.

Table 2. Percentage infestation of mistletoe in fruit and timber tree spices among different land use types

\begin{tabular}{lcc}
\hline Habitat/ Land use & $\begin{array}{r}\text { Percentage of infested fruit } \\
\text { trees }\end{array}$ & $\begin{array}{c}\text { Percentage of infested timber } \\
\text { trees }\end{array}$ \\
\hline Home gardens & 67.8 & 39.7 \\
Roadsides & 16.7 & 30.88 \\
Mixed cropping systems & 5.4 & 13.24 \\
Demonstrations & 5.0 & 5.88 \\
Plantations & 5.0 & 10.29 \\
\hline
\end{tabular}


Seven different parasitic plant species were identified, namely, Dendrophthoe neilgherrensis, D. falcata, Scurrula cordifolia, S. parasitica, Taxillus incanus, Viscum articulatum and V. orientale, infesting fruit and timber tree species (Table 3). All the species were perennial, hemi-parasitic mistletoe species, belonging to the families Loranthaceae or Viscaceae. Dendrophthoe neilgherrensis and D. falcata, which are indigenous to Sri Lanka and India (de Vlas and de Vlas-de Jong, 2014) were the most predominant parasitic plant species in all host fruit and timber trees and in most agro-climatic zones studied. Other four species were relatively in less abundance. The mistletoe species $D$. neilgherrensis and D. falcata also infested many host fruit tree species (i.e. 14 and 20 species, respectively). Other mistletoe species were relatively more specific on their hosts, and were present in less number of host species. Taxillus incanus was present only in one host fruit tree species, Muntingia calabura L. The mistletoes of families Loranthaceae and Viscaceae in Sri Lanka are generally regarded as water-tapping species (Tennakoon and Weerasooriya, 1998). Taxillus incanus, an endemic species to Sri Lanka, was reported in the montane and Low-country Wet Zone of Sri Lanka (Tennakoon and Weerasooriya, 1998), and scattered in the Low Country Dry Zone (Dassanayake, 1987). However, the host species were not reported in the previous reports.

Table 3. Distribution of different parasitic plant species infesting fruit and timber trees

\begin{tabular}{|c|c|c|c|c|}
\hline Parasitic plant species & Family & Agro-climatic zone & $\begin{array}{c}\% \text { of } \\
\text { occurrence } \\
\text { in fruit } \\
\text { trees }\end{array}$ & $\begin{array}{c}\% \text { of } \\
\text { occurrence } \\
\text { in timber } \\
\text { trees }\end{array}$ \\
\hline Dendrophthoe falcata & Loranthaceae & $\begin{array}{c}\text { IL, IM, IU, } \\
\text { WL,WM,WU }\end{array}$ & 47.77 & 82.09 \\
\hline $\begin{array}{l}\text { Dendrophthoe } \\
\text { neilgherrensis }\end{array}$ & Loranthaceae & $\begin{array}{l}\text { IL, IM, IU, WL, } \\
\text { WM, WU }\end{array}$ & 38.91 & 8.96 \\
\hline Scurrula cordifolia & Loranthaceae & IL, IM, WM, WU & 3.77 & 1.49 \\
\hline Scurrula parasitica & Loranthaceae & IL, WL & 0.0 & 2.99 \\
\hline Taxillus incanus & Loranthaceae & WM, IU & 2.09 & 0.0 \\
\hline Viscum articulatum & Viscaceae & IL, IM, WM & 1.26 & 1.49 \\
\hline Viscum orientale & Viscaceae & IL, IM, WM & 6.28 & 1.49 \\
\hline
\end{tabular}

$I L=$ Low country Intermediate Zone; IM = Mid country Intermediate Zone; IU = Upcountry Intermediate Zone; $W L=$ Low country Wet Zone; WM = Mid country Wet Zone; WL = Low Country Wet Zone;

Dendrophthoe falcata was the most abundant mistletoe species that occurred in timber species, which accounted for more than $82 \%$ of the mistletoes identified in this study (Table 3 ) and in most number of agro-climatic regions. This species also infested 16 different timber tree species. Contrary to in the fruit trees, D. neilgherrensis occurrence was only $9 \%$ in timber trees, infesting only nine different timber species. Scurrula cordifolia, S. parasitica, $V$. articulatum and $V$. orientale affected timber species in a less frequency, and a less number of species. Taxillus incanus parasitized fruit trees, but not timber species while $S$. parasitica was observed parasitizing timber trees, not fruit trees. Other mistletoe species were common to both fruit and timber species. 
The details of infestation of fruit tree species by parasitic plants are presented in Table 4 .

Table 4. Details of fruit tree species infested by parasitic plants

\begin{tabular}{|c|c|c|c|c|c|}
\hline $\begin{array}{c}\text { Common } \\
\text { Name of Fruit } \\
\text { species }\end{array}$ & Scientific Name & $\begin{array}{l}\text { Habitat/ } \\
\text { Land use } \\
\text { type }\end{array}$ & $\begin{array}{c}\text { Percent } \\
\text { infested } \\
\text { Trees* }\end{array}$ & $\begin{array}{l}\text { Mistletoe } \\
\text { Species§ }\end{array}$ & $\begin{array}{l}\text { Extent of } \\
\text { damage } \dagger\end{array}$ \\
\hline $\begin{array}{l}\text { Ambul Dodam } \\
\text { (Sour orange) }\end{array}$ & Citrus aurantium & $\mathrm{a}, \mathrm{d}$ & 1.3 & 2,6 & $25-35$ \\
\hline $\begin{array}{l}\text { Anoda } \\
\text { (Soursop) }\end{array}$ & Annona muricata & $\mathrm{a}, \mathrm{e}$ & 2.1 & 1,2 & $5-15$ \\
\hline Avocado & Persea americana & $a, b, e, f$ & 6.3 & 1,2 & $3-15$ \\
\hline Beli (Bael) & Aegle marmelos & $\mathrm{a}$ & 3.8 & 2,6 & $1-60$ \\
\hline $\begin{array}{l}\text { Delum } \\
\text { (Pomegranate) }\end{array}$ & Punica granatum & $\mathrm{a}, \mathrm{d}$ & 4.2 & $1,2,5$ & $1-45$ \\
\hline $\begin{array}{l}\text { Divul (Wood } \\
\text { apple) }\end{array}$ & Limonia acidissima & $\mathrm{a}$ & 1.3 & 2 & $5-20$ \\
\hline Guava & Psidium guajava & $a, b, e$ & 3.8 & 1,2 & $5-10$ \\
\hline Jack & $\begin{array}{l}\text { Artocarpus } \\
\text { heterophyllus }\end{array}$ & $\mathrm{a}, \mathrm{c}$ & 2.5 & 2 & $5-15$ \\
\hline Jam & $\begin{array}{l}\text { Muntingia calabura } \\
\text { L. }\end{array}$ & $\mathrm{a}, \mathrm{c}$ & 2.1 & 2,4 & $10-20$ \\
\hline Jama Naran & $\begin{array}{l}\text { Citrus reticulata } \\
\text { var. }\end{array}$ & $\mathrm{a}$ & 2.9 & $1,3,6$ & $10-15$ \\
\hline Jambola & Citrus grandis & $\mathrm{a}$ & 3.4 & $2,3,6$ & $5-50$ \\
\hline Jambu & $\begin{array}{l}\text { Syzygium } \\
\text { samarangense }\end{array}$ & $\mathrm{a}$ & 3.4 & 2 & $5-85$ \\
\hline Koon & Schleichera oleosa & $\mathrm{c}$ & 0.4 & 6 & 5 \\
\hline Kottamba & Terminalia catappa & $\mathrm{c}$ & 1.3 & 2 & 5 \\
\hline Laavulu & $\begin{array}{l}\text { Pouteria } \\
\text { campechiana }\end{array}$ & $\mathrm{a}$ & 0.4 & 1,2 & $15-25$ \\
\hline Lemon & Citrus limon & $\mathrm{a}, \mathrm{e}$ & 1.3 & 1,6 & $5-15$ \\
\hline Lovi & Flacourtia inermis & $\mathrm{a}$ & 0.4 & 3 & 5 \\
\hline Mango & Mangifera indica & $\begin{array}{c}\mathrm{a}, \mathrm{b}, \mathrm{c}, \mathrm{d} \\
\mathrm{e}, \mathrm{f}\end{array}$ & 40.6 & 1,2 & $5-95$ \\
\hline Naran & Citrus reticulata & $a, b, e, f$ & 3.8 & $1,2,3,5$ & $5-50$ \\
\hline Nelli & Phyllanthus emblica & $\mathrm{e}$ & 0.8 & 1,5 & $20-30$ \\
\hline Orange (local) & Citrus sinensis & e & 9.6 & 1,2 & $5-25$ \\
\hline Rambutan & $\begin{array}{l}\text { Nephelium } \\
\text { lappaceum }\end{array}$ & $\mathrm{a}, \mathrm{d}, \mathrm{e}, \mathrm{f}$ & 0.8 & 1,2 & $5-25$ \\
\hline Seeni anodha & Annona cherimola & $\mathrm{a}$ & 0.4 & 2 & 5 \\
\hline
\end{tabular}




\begin{tabular}{|c|c|c|c|c|c|}
\hline Uguressa & Flacourtia indica & $\mathrm{a}, \mathrm{c}, \mathrm{f}$ & 1.7 & 1,2 & 5 \\
\hline Weli anoda & Annona reticulata & $\mathrm{a}$ & 0.4 & 2 & $20-60$ \\
\hline Weralu & $\begin{array}{l}\text { Elaeocarpus } \\
\text { serratus }\end{array}$ & $\mathrm{a}$ & 0.4 & 1 & 5 \\
\hline \multicolumn{6}{|c|}{$\begin{array}{l}\text { a: Home gardens, } b: \text { Kandyan forest gardens, } c: \text { Road sides, } d: \text { Demonstration areas, } e: \text { Mixed cropping systems, } \\
\quad f: \text { Plantations. }\end{array}$} \\
\hline \multicolumn{6}{|c|}{$\begin{array}{l}* \% \text { infestation }=\frac{\text { No.of Infested trees of the particular spp }}{\text { Total No.of infested fruit trees }} * 100 \\
\$ 1: \text { Dendrophthoe neilgherrensis, 2: Dendrophthoe falcata, 3: Scurrula cordifolia, 4: Taxillus incanus, 5: Viscum } \\
\quad \text { articulatum, 6: Viscum orientale, 7: Scurrula parasitica } \\
+ \text { As measured by approximate \% canopy covered by parasitic plants }\end{array}$} \\
\hline
\end{tabular}

Twenty-seven fruit tree species were identified to be infested by different parasitic plant species (Table 4). Mangifera indica was the most abundant fruit tree species infested with mistletoes among all types of vegetation with the highest extent of infestation. Of all the fruit species that were infested with the parasitic plants, approximately $41 \%$ was $M$. indica, followed by $C$. sinensis $(9.6 \%)$ and $P$. Americana (6.3\%). Infestation in $P$. americana, $C$. reticulata, $N$. lappaceum and $F$. indica was also quite abundant in many types of vegetation. Mangifera indica was infested in all the districts studied. In some instances, a substantial area of the canopy was covered with parasitic plants, decreasing yields substantially. A considerable number of $A$. marmelos, $P$. granatum, $P$. guajava, $C$. grandis, $S$. samarangense and $C$. reticulate trees were also infested with parasitic plants (Table 4 ).

Some fruit tree species were infested with more than one parasitic plant species, where as some were infested specifically with one mistletoe species each. Citrus reticulate was the host tree species infested with most number of mistletoe species (i.e. four species, namely, $D$. neilgherrensis, D. falcata, $S$. cordifolia and V. articulatum). P. granatum, C. reticulate var., $C$ grandis were infested by three different mistletoe species each. Limonia acidissima, $A$. heterophyllus, S. samarangense, S. oleosa, T. catappa, F. inermis, A. cherimola, A. reticulate and $E$. serratus were infested by only one species of mistletoe each. The degree of infestation of fruit species was also different. The highest degree of damage was in jambu ( $S$. samarangense) and mango ( $M$. indica), and some tree canopies were more than $80 \%$ covered by the mistletoes. From the above analysis, mango was identified as the fruit species that was mostly damaged by the mistletoes in the Wet and Intermediate Zones of Sri Lanka. Aegle marmelos, S. samarangense, different Citrus and Annona species were also infested to a considerable level by mistletoes.

Some mistletoe species infested many host fruit tree species (i.e., D. neilgherrensis and D. falcata) and hence, could be called as generalists. However, T. incanus was found to be infesting only $M$. calabura trees. Some parasitic plants are known to demonstrate preferences for particular host plants, while some others are considered as generalists, exploiting resources from several to dozens of host plants (Marvier, 1998). In ecological terms, these generalists are important as they can be supported by multiple hosts. Because the hosts will differ in susceptibility to attack, generalists are likely to alter competitive interactions among hosts and create strong indirect effects, such as apparent competition. The parasitic plants are also likely to play an important role in determining the structure of a wide variety of plant communities as they frequently cause different extent of harm to particular host species, and that parasitic performance can vary greatly depending on the type of host (Marvier, 1998).

The details of infestation of timber tree species by parasitic plants are presented in Table 5. 
Table 5. Details of timber tree species infested by parasitic plants.

\begin{tabular}{|c|c|c|c|c|c|}
\hline Timber tree & Scientific name & $\begin{array}{l}\text { Habitat/ } \\
\text { Land Use }\end{array}$ & $\begin{array}{c}\text { Percent } \\
\text { infested } \\
\text { trees* }\end{array}$ & $\begin{array}{l}\text { Mistleto } \\
\text { e } \\
\text { species } \$\end{array}$ & $\begin{array}{l}\text { Extent of } \\
\text { damage } \dagger\end{array}$ \\
\hline Acacia & Acacia grandifolia & $\mathrm{a}, \mathrm{c}, \mathrm{e}, \mathrm{f}$ & 7.35 & 2 & $5-20$ \\
\hline Albizia & Albizia falcataria & $\mathrm{e}$ & 1.47 & 1,2 & 5 \\
\hline Burutha & $\begin{array}{l}\text { Chloroxylon } \\
\text { swietenia }\end{array}$ & a & 1.47 & 5 & 15 \\
\hline Daminne & Grewia daminae & $\mathrm{e}$ & 1.47 & 2 & 5 \\
\hline Eucalyptus & Eucalyptus obliqua & $\mathrm{a}$ & 1.47 & 2 & 5 \\
\hline Gansooriya & Thespesia populnea & $\mathrm{a}$ & 1.47 & 2 & 10 \\
\hline Sabukku & Grevillea robusta & $\mathrm{f}$ & 2.94 & 2 & 5 \\
\hline Huree mara & Albizia odoratissima & $a, b, c, d, e, f$ & 23.53 & 1,2 & $5-75$ \\
\hline Ipil Ipil & $\begin{array}{l}\text { Leucaena } \\
\text { leucocephala }\end{array}$ & $\mathrm{a}$ & 2.94 & 2 & $5-75$ \\
\hline Jack & $\begin{array}{l}\text { Artocarpus } \\
\text { heterophyllus }\end{array}$ & $\mathrm{a}, \mathrm{c}$ & 14.71 & 2 & $5-10$ \\
\hline Ketakela & Bridelia retusa & $e, f$ & 5.88 & $2,3,7$ & 5 \\
\hline Kumbuk & Terminalia arjuna & $\mathrm{c}$ & 1.47 & 2 & 5 \\
\hline Lunumidella & Melia azedarach & $\mathrm{a}, \mathrm{c}$ & 5.88 & 2 & $5-20$ \\
\hline Maara & Albizia saman & $\mathrm{c}, \mathrm{f}$ & 8.82 & 2,6 & $5-30$ \\
\hline Pihimbiya & Filicium decipiens & $\mathrm{a}, \mathrm{c}$ & 2.94 & 2 & $10-15$ \\
\hline Suriyamaara & Albizia odonatissima & $\mathrm{c}$ & 1.47 & 2 & 20 \\
\hline Turpentine & $\begin{array}{l}\text { Syncarpia } \\
\text { glomulifera }\end{array}$ & $\mathrm{c}$ & 1.47 & 1 & 20 \\
\hline Toona & Toona ciliata & $\mathrm{c}, \mathrm{e}$ & 2.94 & 1,2 & 5 \\
\hline Teak & Tectona grandis & $\mathrm{a}, \mathrm{c}, \mathrm{e}, \mathrm{f}$ & 7.35 & 2,3 & $5-20$ \\
\hline Iron wood & Mesua ferrea & $\mathrm{c}$ & 1.47 & 1 & 2 \\
\hline
\end{tabular}

fa: Homegardens, $b$ : Kandyan forest gardens, $c$ : Road sides, $d$ : Demonstration areas, $e$ : Mixed cropping systems, f: Plantations.

$* \%$ infestation $=\frac{\text { No.of Infested trees of the particular spp }}{\text { Total } N o . \text { f infested fruit trees }} * 100$

§ 1: 1: Dendrophthoe neilgherrensis, 2: Dendrophthoe falcata, 3: Scurrula cordifolia, 4: Taxillus incanus, 5: Viscum articulatum, 6: Viscum orientale, 7: Scurrula parasitica

$\dagger$ As measured by approximate \% canopy covered by parasitic plants

In the present study, huree mara (Albizia odoratissima) was the timber species infested by mistletoes that was present in all the vegetation types. Mistletoe-infested T. grandis and $A$. grandifolia were also abundant in many vegetation types while the mistletoe-infested $A$. heterophyllus, B. retusa, M. azedarach, A. saman, F. decipiens and T.ciliate were also present to a lesser extent in these vegetation types. Albizia odoratissima was the timber species that was mostly infested by mistletoes in this study (approximately $23.5 \%$ of the infested timber species), followed by A. heterophyllus (approximately15\%), A. saman (approximately 9\%), A. grandifolia and T. grandis (approximately 7\% each) of the infested 
timber species. Bridelia retusa and $M$. azedarach were also considerably infested by mistletoes.

Albizia odoratissima and L. leucocephala trees were the most susceptible timber tree species, where up to $75 \%$ of the tree canopy was covered by the mistletoes. Albizia saman was infested by mistletoes covering about $30 \%$ of the canopy followed by A. grandifolia, $M$. azedarach and T. grandis where up to about $20 \%$ of the canopy was covered by the hemiparasites.

Increased occurrence of mistletoes has been reported from many countries including Sri Lanka (Yapa et al., 2015; 2017), Canada (Epp and Tardif, 2004), East Java (Muttaqin et al., 2016), Ghana (Asare-Bediako et al., 2013), India (Thriveni et al., 2002), USA (Agne et al., 2014), etc. The increased occurrence could also be as a result of more conducive environment (i.e. increased dispersal and germination of seeds, absence/decrease of parasites of the mistletoes, etc.) for the mistletoe or decreased vigor of the host tree species. Mistletoes in Sri Lanka are generally regarded as water-tapping species (Tennakoon and Weerasooriya, 1998). Hemiparasites extract water and mineral nutrients from the hosts through haustoria. Such removal of nutrients clearly compromises the host performance exerting deleterious effects (Hautier et al., 2010), and this coupled with high densities of hemiparasites can have drastic effects on the crop, decreasing the productivity, and even death of the host plant in the end. Increased ambient temperature and decreased rainfall have been reported in Sri Lanka (Zoysa and Inoue, 2014) and elsewhere (Lobell and Gourdji, 2012). Such changes in the climate can affect both the host and the parasitic plants individually, leading to changes in the strength of plants (Way, 2011), changes in populations of other animals feeding on the mistletoes, etc. Warming effects has also shown to have extended the altitudinal range of some tree parasitic plants (Dobbertin et al., 2005; Way, 2011). Therefore, attention is required on the causes of increased occurrence of the mistletoes and their control/management strategies.

Present study identified seven species of mistletoe in the wet and intermediate zones of Sri Lanka, belonging to the families Loranthaceae and Viscaceae. In a previous study, Tennakoon and Weerasooriya (1998) identified 9, 12 and 10 hemiparasitic species affecting host plants in the montane, Low Country Wet Zone and Intermediate Zone of Sri Lanka, respectively. All the seven species reported in the present study were also recorded in the previous study by Tennakoon and Weerasooriya (1998). The higher number of mistletoes in the previous study could be due to the more number of ecosystems and the host plant species that have been considered. The present study considered only the economically important fruit and timber tree species, in the Intermediate and Wet Zones of Sri Lanka. Tennakoon and Weerasooriya (1998) also observed D. neilgherrensis and T. incanusonly in montane and lowlands in the Wet Zones, D. falcata in the lowlands in Wet and Intermediate Zones only, $S$. cordifolia and S. parasitica in the Intermediate and Dry Zones only, and V. articulatum and $V$. orientale in the Dry Zone only. In the present study, D. neilgherrensis and D. falcata were observed in the most number of agroclimatic zones, namely, IL, IM, IU, WL, WM and WU. Scurrula cordifolia and S. parasitica were also observed in the Wet Zone, and $V$. articulatum and $V$. orientale were observed in the Wet and Intermediate Zones, showing their presence in more number of habitats than in the earlier study by Tennakoon and Weerasooriya (1998). 


\section{CONCLUSIONS}

The present study identified that perennial fruit and timber tree species in Wet and Intermediate Zones of Sri Lanka were infested by parasitic plants to varying degrees. The identified species of parasitic plants affecting the fruit tree species were D. falcata, $D$. neilgherrensis $S$. cordifolia, $V$. articulatum, T. incanus, $V$. articulatum and $V$. orientale. Among the fruit trees, $M$. indica was the most susceptible fruit tree to the parasitic plants. Dendrophthoe falcata was the most prominent parasitic plant amongst all the fruit and timber tree species reported in the present study. The identified species of parasitic plants affecting the timber tree species were D. falcata, D. neilgherrensis, S. cordifolia, S. parasitica, $V$. articulatum and $V$. orientale. Among the timber species, A. odoratissima was the most susceptible host timber tree to the parasitic plants. Many mistletoes also showed their presence in more number of agroclimatic zones, than has been previously reported.

\section{AKNOWLEDGEMENT}

Financial assistance provided by the PGIA Research Facilitation Fund (Grant 2015-379) and the University of Peradeniya Research grant (RG/AF/2013/06/Ag) are acknowledged.

\section{REFERENCES}

Agne, M.C., Shaw, D.C., Wooley, T.J. and Queijeiro-Bolanos, M.E. (2014). Effects of dwarf mistletoe on stand structure of lodgepole pine forests 21-28 years post-mountain pine beetle epidemic in Central Oregon. Plos One 9(9), 1-13.

Asare-Bediako, E., Addo-Quaye, A.A., Tetteh, J.P., Buah, J.N., Puij,e V.D. and Acheampong, R.A. (2013). Prevalence of mistletoe on citrus trees in the Abura-AsebuKwamankese district of the central region of Ghana. Int. J. Sci. Technol. Res. 2(7), 122-127.

Bell, T.L. and Adams, M.A. (2011). Attack on all fronts: functional relationships between aerial and root parasitic plants and their woody hosts and consequences for ecosystems. Tree Physiol. 31(1), 3-5.

Cameron, D.D., Geniez, J-M., Seel, W.E. and Irving, L.J. (2008). Suppression of host photosynthesis by the parasitic plant Rhinanthus minor. Annals of Bot. 101, 573-578.

Dassanayake, M.D. (1987). Loranthaceae: A revised handbook. The flora of Ceylon. Amerind Publishing Company (Pvt.) Ltd., New Delhi, 6, 123-151.

de Vlas, J. and de Vlas-de Jong, J. (2014). Illustrated field guide to the flowers of Sri Lanka. J \& J de Vlas, Netherlands, 2,189-266.

Dobbertin, M.N., Hilker, N., Rebetez, M., Zimmermann, T., Wohlgemuth, T. and Rigling, A. (2005). The upward shift in altitude of pine mistletoe (Viscum album spp. austriacum) in Switzerland-the result of climate warming? Int. J. Biometeorl. 50, 40-47.

Epp, B. and Tardiff, J.C. (2004). Effects of Lodgepole pine dwarf mistletoe, Arceuthobium americanum, on Jack pine, Pinus banksiana, growth in Manitoba. Can. Field Nat. 118(4), 595-601. 
Hibberd, J.M. and Jeschke, W.D. (2001). Solute flux into parasitic plants. J. Exp. Bot. 52 (363), 2043-2049.

Hull, R.J. and Leonard, O.A. (1964). Physiological aspects of parasitism of mistletoes (Arceuthobium and Phoradendron) 1. The carbohydrate nutrition of mistletoe. Plant Physiol. 39(6), 996-1007.

Lobell, D.B. and Gourdji, S.M. (2012). The influence of climate change on global crop productivity. Plant Physiol. 160(4), 1686-1697.

Marambe, B., Wijesundara, S., Tennakoon, K., Pindeniya, D. and Jayasinghe, C. (2002).Growth and development of Cuscuta chinensis Lam. and its impact on selected crops. Weed Biol. Manag. 2, 79-83.

Marvier, M.A. (1998). Parasite impacts on host communities: Plant parasitism in a California coastal Prairie. Ecol. 79(8), 2616-2623.

Muttaqin, Z., Wasis, B. and Siregar, I. Z. (2016). Assessing intensity of mistletoe infestation in Teak Clonal Seed Orchard (CSO) Padangan, East Java. Procedia Environ. Sci. 33, $404-$ 415.

Nickrent, D.L. and Musselman, L.J. (2010). Introduction to parasitic flowering plants. The Plant Health Instructor [On line]. [Accessed on 02/07/2013] Available at http://www.apsnet.org/edcenter/intropp/pathogengroups/ pages/parasitiplants.aspx

Press, M.C. (1989). Autotrophy and heterotrophy in root hemiparasites. Trends Ecol. Evol. 4, 258-263.

Tennakoon, K.U. and Weerasooriya, A. (1998). Nature's scroungers. The fascinating world of plants parasites. Sri Lanka Nature, 2, 44-58.

Tennakoon, K.U., Chak, W.H. and Bolin, J.F. (2011). Nutritional and isotopic relationships of selected Bornean tropical mistletoe-host associations in Brunei Darussalam. Funct. Plant Biol. 38, 505-513.

Tennakoon, K.U., Chak, W.H., Lim, L.B.L. and Bolin, J.F. (2014). Mineral nutrition of the hyperparasitic mistletoe Viscum articulatum Burm. f. (Viscaceae) in Brunei Darussalam. Plant Species Biol. 29, 101-107.

Thrivveni, M.C., Shivamurthy, G.R., Amruthesh, K.N., Vijay, C.R. and Kavitha, G.R. (2010). Mistletoes and their hosts in Karnataka. J. Am. Sci. 6, 827-835.

Watling, J.R. and Press, M.C. (2001). Impacts of infection by parasitic angiosperms on host photosynthesis. Plant Biol. 3, 244-250.

Watson, D.M. (2009). Parasitic plants as facilitators: more Dryad than Dracula? J. of Ecol. 97, 1151-1159.

Watson, D.M. (2011). Mistletoes of Southern Australia. CSIRO Publishing, Australia, 1-3. Way, D.A. (2011). Parasitic plants and forests: A climate change perspective, Tree Physiol. $31,1-2$. 
Weeraratna, W.G. (1960). The taxonomy of the Loranthaceae of Ceylon. Ceylon Forester, 4(3), 365-375.

Weeraratna, W.G. (1959). The ecology and biology of parasitism of the Loranthaceae of Ceylon. Thesis accepted for Diploma in Forestry, University of Oxford, UK.

Yapa, S.S., Mohotti, A.J., Seneviratne, M.A.P.K., Peiris, B.L. and Tennakoon, K.U. (2017). Effects of mistletoe Dendrophthoe neilgherrensis parasitism on nutmeg (Myristica fragrens) fruit physical qualities. In: B. Marambe (Ed.) Proceedings of the annual Symposium on Minor Export Crops, 4, held on 16-17 March, Peradeniya, Sri Lanka. pp 91-99.

Yapa, S.S., Mohotti, A.J., Seneviratne, M.A.P.K., Peiris, B.L. and Wijesundara, D.S.A. (2015). Occurrence of parasitic plants in spice and beverage crops of Sri Lanka. In: K.D.W. Nanadalal (Ed.), Proceedings of the Peradeniya University International Research Sessions(iPURSE), 19, 5-6 November, University of Peradeniya, Peradeniya, Sri Lanka. p 388.

Zoysa, M.D. and Inoue, M. (2014). Climate change impacts, agroforestry adaptation and policy environment in Sri Lanka. Open J. For. 4, 439-456. 